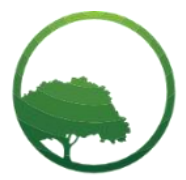

Business \& Social Science IJRBS

\section{Research in Business \& Social Science}

IJRBS VOL 10 NO 6 ISSN: 2147-4478

Available online at www.ssbfnet.com

Journal homepage: https://www.ssbfnet.com/ojs/index.php/ijrbs

\title{
The influence of membership program on customer loyalty mediated by customer satisfaction
}

\author{
(D) Fadhil Muhammad ${ }^{(a)}$ (iD) Fatkhur Rozi ${ }^{(b)}$ (D) Achmad Sani Supriyanto ${ }^{(c)}$ \\ ${ }^{(a)}$ Management Department, Faculty of Economics, State Islamic University of Maulana Malik Ibrahim Malang, Gajayana Street No. 50, Malang, \\ Indonesia \\ (b) Associate Lecturer in Management, Faculty of Economics, State Islamic University of Maulana Malik Ibrahim Malang, Gajayana Street No. 50, \\ Malang, Indonesia \\ ${ }^{(c)}$ Associate Professor in Management, Faculty of Economics, State Islamic University of Maulana Malik Ibrahim Malang, Gajayana Street No. 50, \\ Malang, Indonesia
}

\author{
A R T I C LE INFO \\ Article history: \\ Received 17 August 2021 \\ Received in rev. form 17 Sep. 2021 \\ Accepted 20 Sept 2021 \\ Keywords: \\ Membership Program, Customer \\ Loyalty, Customer Satisfaction \\ JEL Classification: \\ M30
}

\begin{abstract}
A B S T R A C T
This research aimed to determine the effect of the membership programs on customer loyalty of "Kartu Aku" users at Alfamart Sunan Kalijaga Street, Malang City by involving customer satisfaction as mediating variable. This research employed a quantitative approach with a sample of 161 respondents determined by the Slovin formula. Data collection methods used a questionnaire. Meanwhile, the data analysis technique used SEM (Structural Equation Modeling) PLS, and the mediation test used bootstrapping with help of SmartPLS 3.3.3 software. The result showed that variable membership program had a significant effect on variable customer loyalty with $t$-statistics value 15,027, variable membership program had a significant effect on variable customer satisfaction with $t$-statistics value 14,391, variable customer satisfaction had a significant effect on variable customer loyalty with $t$ statistic value 2,818 and variable customer satisfaction significantly mediated the relationship between variable membership program and variable customer loyalty with $t$-statistics value 2,772.
\end{abstract}

(C) 2021 by the authors. Licensee SSBFNET, Istanbul, Turkey. This article is an open access article distributed under the terms and conditions of the Creative Commons Attribution (CC BY) license (http://creativecommons.org/licenses/by/4.0/).

\section{Introduction}

Increasingly, competitive business competition makes companies have to look for new strategies to win the competition. Companies are required not only to sell products, but also how to retain customers. In other words, creating customer loyalty. Alfamart is one of the modern retail networks that applies a point, stamp, and star-based loyalty membership program. This program is known as Kartu Aku Alfamart. The accumulated points could be exchanged for vouchers, products, merchandises or participating in certain sweepstakes from Alfamart. Kartu Aku Alfamart may also be used in various merchants who becomes Alfamart partners. For instance, merchant promos that applies in Malang City including Honda Kartika Sari Putra Garage with discounts ranging from 5\% to 35\% for purchasing motorcycle spare parts, tune ups, cleaning injectors and CVT for various types of motorbikes. This promo is valid until February 15, 2022. Moreover, it also applies at HARRIS Hotel \& Conventions Malang with a 10\% discount for Best Flexible Rate room cost and F\&B a la carte menu at HARRIS cafe restaurants until December 31, 2021. For hostelry and recreation categories apply at Batu Flower Garden with discounted admission tickets starting from Rp. 15.000,00 to Rp. 25,000.00 until October 31, 2021. Last valid at Sengkaling Tourism Park UMM with a 20\% discount on admission tickets which is valid until February 2, 2022.

Kang, Alejandro \& Groza (2015) stated that one of strategies to retain customers is through a customer loyalty program.. Arbore \& Estes (2013) conveyed that customer loyalty programs are marketing tools designed to build customer loyalty through planned reward schemes, which commonly based on the customer's purchase history. Meanwhile, Gdanomi \& Zolfaghari (2013) defined a customer loyalty program as a structured marketing effort which aims for increasing customer loyalty by rewarding their repeat purchase

* Corresponding author. ORCID ID: 0000-0002-0784-6709

(C) 2021by the authors. Hosting by SSBFNET. Peer review under responsibility of Center for Strategic Studies in Business and Finance. https://doi.org/10.20525/ijrbs.v10i6.1362 
behavior. Terms that were frequently used by previous researchers about customer loyalty programs such as membership cards (Filipe, Henriques \& Fatima, 2017). Membership is marked by putting in print a member card. This membership system is designed to offer several benefits that could not be enjoyed by non-member customers. For example, offering promos, discounts, cashback, and special prices with certain conditions for every purchase at the outlets of the company or other companies that partner with it. According to Emor (2016), membership cards in loyalty programs and customer experience could influence customer loyalty to the company.

A Research conducted by Soedjono \& Limantoro (2018) on Sogo Premier Card claimed that Sogo Premier Card was able to maintain customer loyalty of Sogo Department Stores by three indicators, there were reward based bonds, selection and interaction. This is reinforced with a research by Adha, Wahyudi \& Nahar (2018) which stated that there was a significant positive effect of the loyalty program variable on brand loyalty. The same thing was declaired by A'yun (2017) in the result of her research about the benefits of the Larissa Aesthetic Semarang member card, which stated that there was a significant relationship between the benefits of member card and customer loyalty. However, there are other contradictory studies, as said by Jiang \& Zhang (2016) that the Frequent Flyer Program (PFF) had failed to increase customer loyalty. Meanwhile, in that study, customer loyalty was formed based on pricing by the company.

The inconsistency of previous research is interesting for further research with other variables that could explain the relationship between membership programs and customer loyalty. One of the ways to provide services in accordance with customer needs is by implementing a membership program in order to create customer satisfaction (Sthopoulou \& Balabanis, 2016). This is also strengthened by the results of Khairawatia's (2020) research stated that membership programs significantly affected customer satisfaction. Besides, customer satisfaction can also maintain customer loyalty in a company. Another study which conducted by Jazuli (2020) on Umrah Travel customer loyalty denoted that Umrah Travel customer satisfaction significantly increased customer loyalty.

Furthermore, customer satisfaction is a kind of feeling either pleasure or disappointment that arises from comparing the perceived performance of the product or result to expectations (Kotler \& Keller, 2009: 138). If performance fails to fulfil the expectation, customers will be dissatisfied. If the performance matches expectations, the customer will be satisfied. If performance exceeds expectations, the customer will be very satisfied or happy. Meanwhile, Sukmaputra et al. (2017) said that customer satisfaction is the feeling of pleasure and disappointment of consumers after using the product caused by the gap between expectations and perceptions which influenced by internal and external factors.

Based on the explanation above, customer satisfaction is expected to be a solution for conflicting facts and theories. In addition, it could bridge the membership program variable with the customer loyalty variable. This study was conducted to determine the effect of membership programs, customer loyalty and customer satisfaction on Kartu Aku Alfamart members.

\section{Literature Review}

\section{Theoretical and Conceptual Background}

\section{Loyality Program}

According to Curatman, Suroso \& Suliyanto (2020), customer loyalty program is a marketing program designed by retailers to gain customer loyalty and increase profits through providing incentives to precious customers (Yi \& Jeon, 2003). Meanwhile, Leenheer et al. (2007) defined the customer loyalty program in the form of an integrated marketing system that purposes to provide rewards and encourage loyal behavior through incentives. Companies utilized several terms regarding rewards for customer loyalty program even though the benefits offered were relatively same. Rewards for customer loyalty programs in the hotel business are called guest frequent programs, while in the airline business is called frequent flyer programs. Customer loyalty program rewards in the retail industry uses the terms such bonus program, customer club, membership card, fly buys, and others (Butscher, 2002).

\section{Membership Program}

The membership program is a common program carried out by companies. The company uses the membership system to offer several benefits for customers, for example, offering promos, discounts, cashback, and special prices with certain conditions for every purchase at the outlet of the company or other companies that partner with it. Membership is marked by the presence of a membership card. Someone who could become members in an organization or a company may be individuals or purchasing agents whose services will also be used by others. Member cards could be used by someone who is considered eligible as a member (Curatman, Suroso \& Suliyanto, 2020).

\section{Customer Loyalty}

Customer loyalty is the magnitude of customer possibility to repurchase and their willingness to become partners for the company. Being a partner means being willing to buy products or services in larger quantities, provide positive recommendations and also inform to the company if there is something error occurs in service operations (Kotler, Bowen \& Makens, 1999). Whereas, Kotler \& Keller (2016) argued a deeply held commitment to buy or to re-support a preferred product or service in the future even though the influence of situation and marketing efforts potentially could trigger the customers to switch. 


\section{Customer Satisfaction}

Customer satisfaction is a kind of feeling either pleasure or disappointment that arises from comparing the perceived performance of the product or result to expectations (Kotler \& Keller, 2009:138). Ahmed et al., (2010) argue that customer satisfaction is a measurement of the products and services set by the company to fulfil or to exceed customer expectations. Then, customer satisfaction is the customer's evaluation of the product or service in terms of the product or service has already complied the needs and the expectations of customers (Bitner \& Zeithaml, 2003).

\section{Research Framework and Hypothesis Formation}

This study consists of the independent variable - namely the membership program, the dependent variable - namely customer loyalty, and the mediating variable - namely customer satisfaction. For more details, see the image below:

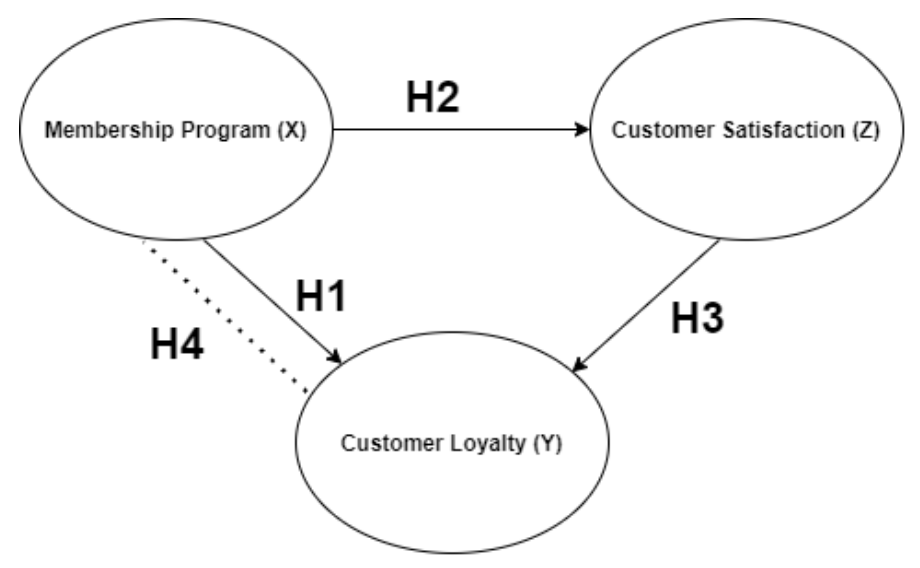

Figure 1: Research Framework; Source: Processed Researcher (2021)

H1: Membership Program had a significant effect on Customer Loyalty

H2: Membership Program had a significant effect on Customer Satisfaction

H3: Customer Satisfaction had a significant effect on Customer Loyalty

H4: Customer Satisfaction had a mediating effect on relationship between Membership Program and Customer Loyalty

\section{Research and Methodology}

\section{Data Collection}

The population in this study were 270 users of Kartu Aku who transacted at Alfamart Sunan Kalijaga street, Malang City. Meanwhile, sampling was carried out by using the Stratified Random Sampling technique, which is a random sampling technique. The method of calculating the number of samples utilized the Slovin sampling method, which is as follows:

$\mathrm{n}=\frac{\mathrm{N}}{1+\mathrm{N}(\alpha)^{2}}($ Sugiono. 2011)

$\mathrm{n}=\frac{270}{1+270 \cdot(0,05)^{2}}$

$\mathrm{n}=161$

Accordingly, based on the calculation of the number of samples by using the Slovin method, the number of samples in this study was 161 samples.

The technique to collect the data employed a questionnaire method. According to Abdillah \& Hartono (2015), the questionnaire is a primary data collection method by engaging amount of question items or statements with a certain format. Those questions or statements includes several variables to be investigated.

\section{Data Analysis}

The data analysis method employed SEM (Structural Equation Modeling) based on Partial Least Square (PLS) by using SmartPLS 3.3.3 software application.

\section{Measurement}

This research applied three variables, each of those three variables were measured through indicators from several sources. The Variable Membership Program was measured by 4 indicators obtained from Soedjono \& Limantoro (2018), namely reward based bonds, social bonds, customization bonds and structural bonds. Then, the Customer Loyalty variable was measured by 4 indicators 
according to Griffin (2005), namely doing regular repeat purchases, buying between product or service lines, recommending products or services to others and showing immunity to competitors. Lastly, the Customer Satisfaction variable was measured by 3 indicators according to Kotler \& Keller (2012), there were Complaints and Suggestions System, Customer Satisfaction Survey, and Lost Customer Analysis.

\section{Variable \& Indicators}

The measurement method in this study employed a Likert scale. Amirullah (2013: 97) elucidated that the Likert scale is used to exemplify the degree of agreeing and disagreeing as for each statement which related to the object being assessed. Based on this theory, the assessment started from 1-5. Respondents would give score 1 for strongly disagree, 2 for disagreeing, 3 for neutral, 4 for agree and 5 for strongly agree.

\section{Result and Discussion}

\section{Demographic of Respondent}

Based on the results of data processing, from 161 respondents (100\%) a number of 65 respondents (40\%) were male and 96 respondents $(60 \%)$ were female. Based on the occupations, there were 94 respondents (58\%) work as students, 7 respondents (4\%) work as civil servants/ASN, 33 respondents $(21 \%)$ as private employees, 13 respondents $(8 \%)$ have entrepreneurial backgrounds, while the other 14 respondents $(9 \%)$ as housewives. Whereas, based on the education levels, amount of 27 respondents (17\%) have a high school education background, 101 respondents $(63 \%)$ have an undergraduate education background, while 26 other respondents $(16 \%)$ have a master's education background and the remaining 7 respondents (4\%) have a doctoral education background. Lastly, based on the frequency of shopping, 47 respondents (29\%) have a shopping frequency of once a month, meanwhile 58 respondents (36\%) choose to shop twice a month, while 34 respondents (21\%) shop three times a month, other 19 respondents $(12 \%)$ shop four times a month, and the rest of 3 respondents $(2 \%)$ have a daily shopping frequency.

\section{Outer Model Test Results}

An instrument is approved to fulfil the convergent validity test if it has a loading factor value above or greater than 0.7 .

Table 1: Convergent Validity

\begin{tabular}{|c|c|c|c|c|}
\hline Variable & Indicator & Loading Factor & Cut Off & Description \\
\hline \multirow[t]{11}{*}{ Membership Program } & X.1 & 0,849 & 0,7 & Valid \\
\hline & X.10 & 0,860 & 0,7 & Valid \\
\hline & X.11 & 0,761 & 0,7 & Valid \\
\hline & X.2 & 0,766 & 0,7 & Valid \\
\hline & X.3 & 0,757 & 0,7 & Valid \\
\hline & X.4 & 0,776 & 0,7 & Valid \\
\hline & $X .5$ & 0,864 & 0,7 & Valid \\
\hline & X.6 & 0,857 & 0,7 & Valid \\
\hline & $\mathrm{X} .7$ & 0,757 & 0,7 & Valid \\
\hline & $\mathrm{X} .8$ & 0,768 & 0,7 & Valid \\
\hline & X.9 & 0,844 & 0,7 & Valid \\
\hline \multirow[t]{5}{*}{ Customer Loyalty } & Y.1 & 0,805 & 0,7 & Valid \\
\hline & Y.2 & 0,846 & 0,7 & Valid \\
\hline & Y.3 & 0,845 & 0,7 & Valid \\
\hline & Y.4 & 0,782 & 0,7 & Valid \\
\hline & Y.5 & 0,754 & 0,7 & Valid \\
\hline \multirow[t]{4}{*}{ Customer Satisfaction } & Z.1 & 0,841 & 0,7 & Valid \\
\hline & $\mathrm{Z} .2$ & 0,836 & 0,7 & Valid \\
\hline & $\mathrm{Z} .3$ & 0,889 & 0,7 & Valid \\
\hline & Z.4 & 0,741 & 0,7 & Valid \\
\hline
\end{tabular}

Source: Processed Primary Data (2021) 
Table 4.5 elaborated all items that measure membership, customer loyalty, and customer satisfaction programs had reached the required value, namely the loading factor value $>0.7$. Therefore, it could be concluded that all items in the instrument were declared valid in measuring each variable.

\section{Discriminant Validity Test Result}

Discriminant validity is calculated using cross correlation with the criteria of an indicator being declared valid in measuring the corresponding variable, if the loading factor value in corresponding variable is greater than the indicator correlation value in other variables.

Table 2: Discriminant Validity Test Using Cross Loading

\begin{tabular}{|c|c|c|c|c|}
\hline Variable & Indicator & $\mathbf{x}$ & $\mathbf{y}$ & $\mathbf{z}$ \\
\hline \multirow[t]{11}{*}{ Membership Program } & $\mathrm{X} .1$ & 0,849 & 0,710 & 0,552 \\
\hline & X.10 & 0,860 & 0,741 & 0,646 \\
\hline & X.11 & 0,761 & 0,659 & 0,547 \\
\hline & $\mathrm{X} .2$ & 0,766 & 0,660 & 0,526 \\
\hline & X.3 & 0,757 & 0,610 & 0,476 \\
\hline & X.4 & 0,776 & 0,657 & 0,519 \\
\hline & $\mathrm{X} .5$ & 0,864 & 0,720 & 0,580 \\
\hline & X.6 & $\mathbf{0 , 8 5 7}$ & 0,731 & 0,614 \\
\hline & $\mathrm{X} .7$ & 0,757 & 0,721 & 0,419 \\
\hline & X.8 & 0,768 & 0,700 & 0,474 \\
\hline & X.9 & 0,844 & 0,822 & 0,602 \\
\hline \multirow[t]{5}{*}{ Customer Loyalty } & Y.1 & 0,735 & 0,805 & 0,454 \\
\hline & Y.2 & 0,790 & 0,846 & 0,524 \\
\hline & Y.3 & 0,807 & $\mathbf{0 , 8 4 5}$ & 0,465 \\
\hline & Y.4 & 0,573 & $\mathbf{0 , 7 8 2}$ & 0,769 \\
\hline & Y.5 & 0,594 & 0,754 & 0,664 \\
\hline \multirow[t]{4}{*}{ Customer Satisfaction } & Z.10 & 0,651 & 0,571 & 0,841 \\
\hline & $\mathrm{Z} .2$ & 0,556 & 0,539 & $\mathbf{0 , 8 3 6}$ \\
\hline & $\mathrm{Z} .3$ & 0,555 & 0,658 & $\mathbf{0 , 8 8 9}$ \\
\hline & Z.4 & 0,462 & 0,551 & 0,741 \\
\hline
\end{tabular}

Source: Processed Data Primary (2021)

Table 2 described that overall indicators of the variables produced loading factor values $>$ cross correlation on other variables. This indicated that each indicator could be claimed capable to measure the latent variable in accordance with the indicator.

\section{Construct Reability Test}

Table 3: Construct Reability Test

\begin{tabular}{llll}
\hline Variable & Composite Reliability & Cronbach's Alpha & Information \\
\hline Customer Loyalty & 0,903 & 0,866 & Fulfilled \\
\hline Customer Satisfaction & 0,897 & 0,846 & Fulfilled \\
\hline Membership Program & 0,953 & 0,946 & Fulfilled \\
\hline
\end{tabular}

Source: Processed Data Primary (2021)

Table 3 explained that the Cronbach alpha values for each variables were greater than 0.6 and the composite reliability value of all variables had values greater than 0.6. This denoted that all indicators could be stated reliable in measuring the latent variables.

\section{Inner Model Test Results}

Testing of the inner model was carried out by observing the R-Square value which was the model of goodness-fit test. According to Jaya \& Sumertajaya (2008) Goodness of Fit Model is measured by utilizing R-square dependent latent variable with the same interpretation as regression; Q-Square predictive relevance for structural models, measuring how good the conservation value which 
is generated by the model and also the estimated parameters. The magnitude of Q2 has a value with a range of $0<\mathrm{Q} 2<1$, which means the closer to 1, the better the model. The quantity of Q2 is equivalent to the coefficient of total determination in path analysis.

Table 4: Results of the Coefficient of Determination

\begin{tabular}{llll}
\hline Variable & R-Square & $\mathbf{R}^{2}$ & Q Square \\
\cline { 1 - 2 } Customer Loyalty & 0,787 & 0,787 & Q2 $=1-(1-\mathrm{R} 2) \times(1-\mathrm{R} 2)$ \\
\cline { 1 - 2 } Customer Satisfaction & 0,456 & 0,456 & Q2 $=1-(1-0,787) \times(1-0,456)=0,884$ \\
\hline
\end{tabular}

Source: Processed Primary Data (2021)

Table 4 showed that the R-square value of the Customer Loyalty variable was 0.787 . The R-square value exemplified that $78.7 \%$ of the Customer Loyalty variable could be influenced by the Customer Satisfaction variable $(\mathrm{Z})$ and the Membership Program variable (X). While the other $21.3 \%$ were influenced by other variables outside the study. Besides, Table 4 denoted that the R-square value of the Customer Satisfaction variable with a value of 0.456 . The R-square value revealed that $45.6 \%$ of the Customer Satisfaction (Z) variable were influenced by the Customer Loyalty variable (Y) and the Membership Program variable (X). While the other 54.4\% were influenced by other variables outside the research.

Furthermore, from the calculation results above, it was discovered that the Q2 value was 0.884 . It meant that the diversity of data from research that could be explicated by the structural model designed was $88.4 \%$, while the remaining $11.6 \%$ was explicated by other factors outside the model. Based on the table 4 , it could be argued that the structural model in this study was quite good because it was close to the value 1 .

Table 5: The Goodness of Fit Model Test

\begin{tabular}{lcc}
\hline Variable & R Square & AVE \\
\hline Membership Program & & 0,651 \\
\hline Customer Loyalty & 0,787 & 0,652 \\
\hline Customer Satisfaction & 0,456 & 0,686 \\
\hline Average & $\mathbf{0 , 6 2 2}$ & $\mathbf{0 , 6 6 3}$
\end{tabular}

Source: Processed Data Primary (2021)

\section{Hypothesis Testing Result}

Hypothesis testing in this research was based on the value of $t$-statistics, which the test criteria were if the value of $t$-statistics (tcount) $>$ t-table (1.96), then it showed a significant effect.

Table 6: Hypothesis Testing Result

\begin{tabular}{llllll}
\hline Hypothesis & Effect & $\begin{array}{l}\text { Path } \\
\text { Coefficient }\end{array}$ & T Statistic & P Value & Notes \\
\hline H1 & X->Y & 0,736 & 15,027 & 0,000 & Significant \\
\hline H2 & X $->\mathrm{Z}$ & 0,675 & 14,391 & 0,000 & Significant \\
\hline H3 & $\mathrm{Z}->\mathrm{Y}$ & 0.204 & 2.818 & 0,005 & Significant \\
\hline H4 & $\mathrm{X}->\mathrm{Z}->\mathrm{Y}$ & 0,138 & 2,773 & 0,006 & Significant \\
\hline
\end{tabular}

Source: Processed Primary Data (2021)

Based on the table above, it could be discovered that $\mathrm{H} 1, \mathrm{H} 2, \mathrm{H} 3, \mathrm{H} 4$ were accepted.

\section{Discussion}

\section{The Influence of Membership Program on Customer Loyalty}

The results of the study showed that the membership program had a significant effect on customer loyalty with four indicators, namely reward based bonds, social bonds, structural bonds and customization bonds were able to create customer loyalty to the company. Alfamart minimarkets could increase and maintain customer loyalty through the issuance of Kartu Aku which provided many benefits for members. 
This research was also supported by the results of the research conducted by Ovika Khurrota A'yun (2017) and Keizia Laureina Emor (2016) which revealed that loyalty programs and membership programs brought a positive and significant influence on customer loyalty.

\section{The Influence of Membership Program on Customer Satisfaction}

Based on the research had been carried out, it could be obtained that the membership program significantly influenced towards to the customer satisfaction. Through the indicators of reward based bonds, social bonds, structural bonds and customization bonds, it could increase the customer satisfaction to the company. The use of Kartu Aku when transacting at Alfamart created its own satisfaction for members. As Aku Card users, customers gained some accesses to criticize and to provide suggestions regarding facilities, benefits or services provided to members.

In addition, this study was also strengthened by the results of the study conducted by Salihah Khairawatia (2020) toward to the Alfamart minimarket. It was found that the use of member cards at Alfamart minimarkets significantly affected customer satisfaction.

\section{The Influence of Customer Satisfaction on Customer Loyalty}

From the results of data processing, it could be seen that customer satisfaction significantly influenced customer loyalty with indicators of complaints and suggestions, customer satisfaction surveys and lost customer analysis. Customers who were satisfied shopping at Alfamart would turn out to be loyal customers of the company by making repeated purchases and buying between product and service lines.

According to the research conducted by I Gede Aryana Mahayasa and N M. Putri Martayanti (2020) towards to members of the "Dharma Dhita" Savings and Loan Cooperative (KSP) in Sanur, Bali conveyed that the satisfaction of cooperative members created a sense of ownership and a sense of loyalty to KSP Dharma Dhita. In addition, Ade Permata Surya (2019) in his research on Grab users as online transportation proved that Grab passenger satisfaction could increase the motivation for grab users to return using this online transportation service.

\section{The Influence of Membership Program on Customer Loyalty Mediated by Customer Satisfaction}

In this study, it was found that there was a role of customer satisfaction in mediating the relationship between the membership program variable and the customer loyalty variable. Customer satisfaction indicators, namely complaints and suggestions, customer satisfaction surveys and lost customer analysis, indirectly affected Kartu Aku users to continue shopping at Alfamart. When the customers felt satisfied with the facilities, benefits or services provided by the Kartu Aku membership, they would have the loyalty to shop at one certain store, company or brand. The customer loyalty might be measured by doing regular repeat purchases, buying between product or service lines, recommending products or services to others and showing immunity to competitors.

The results of the research conducted by Zakaria, Rahman, Othman, Yunus, Dzulkipli, \& Osman (2014) about the relationship between loyalty programs, customer loyalty and customer satisfaction in the retail industry found that loyalty programs brought a significant effect on customer satisfaction and customer loyalty in the retail industry.

\section{Conclusion}

Based on the results of data analysis and discussions related to membership, customer satisfaction and customer loyalty programs, the following conclusions could be drawn:

i. $\quad$ The results of direct hypothesis testing indicated that the membership program had a significant effect on customer loyalty towards to Kartu Aku users who transacted at Alfamart Sunan Kalijaga Sreet. Malang city.

ii. The results of direct hypothesis testing show pointed out that the membership program had a significant effect on customer satisfaction for Kartu Aku users who transacted at Alfamart Sunan Kalijaga Sreet. Malang city.

iii. $\quad$ The results of direct hypothesis testing denoted that the customer satisfaction had a significant effect on customer loyalty towards to Kartu Aku users who transacted at Alfamart Sunan Kalijaga Sreet. Malang city.

$i v$. The results of indirect hypothesis testing showed that the customer satisfaction significantly mediated the relationship between membership programs and customer loyalty for Kartu Aku users who transacted at Alfamart Sunan Kalijaga Sreet. Malang city.

Adding insight related to the effect of membership programs on customer loyalty mediated by customer satisfaction for Kartu Aku users at Alfamart Sunan Kalijaga Street Malang City and providing empirical evidences about the effect of membership programs on customer loyalty mediated by customer satisfaction on Kartu Aku users at Alfamart Sunan Kalijaga Street Malang City.

This research could be used as a reference for shop owners or retail industry to create customer loyalty and increase customer satisfaction by implementing a membership system.

\section{References}


Adha, M.A., Wahyudi, R., \& Nahar, F.N. (2018). Pengaruh Program Loyalitas Terhadap Kesetiaan Konsumen pada Industri Halal di Yogyakarta. Ihtifaz: Journal of Islamic Economics, Finance, and Banking, 1(1\&2), 69-88. https://doi.org/10.12928/ijiefb.v1i1.287

Abdillah, Willy \& Hartono, Jogiyanto. (2015). Partial Least Square (PLS)- Alternatif Structural Equation Modelling (SEM) dalam Penelitian Bisnis. Yogyakarta: CV. Andi Offset.

Ahmed, I., Nawaz, M. M., Usman, A., Shaukat, M. Z., Naveed Ahmed, N., \& Rehman, W. (2010). A mediation of customer satisfaction relationship between service quality and repurchase intentions for the telecom sector in Pakistan: A case study of university students. African Journal of Business Management, 4(16), 3457-3462.

Amirullah. (2013). Metode Penelitian Manajemen, Cetakan 1. Malang: Bayumedia Publishing.

Arbore, A., \& Estes, Z. (2013). Loyalty Program Structure and Consumers' Perceptions of Status: Feeling Special in a Grocery Store?. Journal of Retailing and Consumer Services, 20(5), 439-444. https://doi.org/10.1016/j.jretconser.2013.03.002

A'yun, O.K. (2017). Hubungan Kualitas Pelayanan Larissa Aesthetic Center Semarang dan Manfaat Kepemilikan Member Card Privilege Terhadap Loyalitas Pelanggan. Interaksi: Jurnal Ilmu Komunikasi, 6(2), 27-31. https://doi.org/10.14710/interaksi.6.2.27-31

Emor, K.L. (2016). The Influence of Loyalty Program Membership Card and Customer Experience on Customer Loyalty at The Urban Gym Aston Hotel Manado. Jurnal EMBA, 4(2), 372-381. https://doi.org/10.35794/emba.4.2.2016.13048

Filipe, S., Henriques, S., \& Fatima, M.De. (2017). Customers' relationship with their grocery store: Direct and moderating effects from store format and loyalty programs. Journal Retailing and Consumer Service, 37, 78-88. https://doi.org/10.1016/j.jretconser.2017.03.002

Griffin, Jill. (2005). Customer Loyalty: Menumbuhkan dan Mempertahankan Kesetiaan Pelanggan (Edisi Revisi dan Terbaru). Jakarta: Erlangga.

Jaya, I .G. N. M \& Sumertajaya, I. Made. (2008). Pemodelan Persamaan Struktural dengan Partial Least Square. Semnas Matematika dan Pendidikan Matematika.

Jazuli, S.F. (2020). Pengaruh Nilai yang Diterima dan Kepuasan Konsumen Terhadap Loyalitas Konsumen Pada Travel Umroh, Proceeding. The 11 th Industrial Research Workshop and National Seminar Bandung, 26-27 Agustus 2020.

Jiang, H., \& Yahua Zhang, Y. (2016). An investigation of service quality, customer satisfaction and loyalty in China's airline market. Journal of Air Transport Management, 57, 80-88. https://doi.org/10.1016/j.jairtraman.2016.07.008

Kang, J., Alejandro, T. B., \& Groza, M. D. (2015). Customer-Company Identification and The Effectiveness of Loyalty Programs. Journal of Business Research, 68(2), 464-471. https://doi.org/10.1016/j.jbusres.2014.06.002

Khairawatia, S. (2020). Effect of Customer Loyalty Program on Customer Satisfaction and Its Impact on Customer Loyalty. International Journal of Research in Business and Social Science, 9(1), 15-23. https://doi.org/10.20525/ijrbs.v9i1.603

Kotler, P., \& Keller, Kevin L. (2009). Manajemen Pemasaran Edisi Ketiga Belas Jilid 1. Jakarta: Erlangga.

Kotler, P., Bowen, J., \& Makens, J. (1999). Marketing for Hospitality and Tourism, (International ed). New Jersey: Prentice Hall.

Kotler, P., \& Keller, Kevin L. (2016). Manajemen Pemasaran. Jakarta: PT. Macaman Jaya Cemerlang.

Mahayasa, I.G.A., \& Putri Martayanti, N.M.P. (2020). Analysis of The Influence of Member's Commitment and Satisfaction on Loyalty of Cooperative Member. Warmadewa Management and Business Journal, 2(1), 48-55.

Soedjono, W. \& Limantoro, F. (2018). Analisis Kegiatan Customer Relationship Management Melalui Membership Card Untuk Meningkatkan Loyalitas Konsumen: Studi Kasus Pada Sogo Premier Card. EXPOSE-Jurnal Ilmu Komunikasi, 1(2), 123133. http://dx.doi.org/10.33021/exp.v1i2.458

Stathopoulou, A \& Balabanis, G. (2016). The effects of Loyalty Programs on Customer Satisfaction, Trust, and Loyalty Toward High and Low-end Fashion Retailers. Journal of Business Research, 69(12), 5801-5808. https://doi.org/10.1016/j.jbusres.2016.04.177

Surya, P. A. (2019). Customer Loyalty From Perspective Of Marketing Mix Strategy And Customer Satisfaction A Study from Grab - Online Transportation in Era of Industrial Revolution 4.0. MIX: Jurnal Ilmiah Manajemen, 9(3), $394-406$. https://dx.doi.org/10.22441/mix.2019.v9i3.001

Zakaria, I., Rahman, B.A., Othman, A.K., Yunus, N.A.M., Dzulkipli, M.R., \& Osman, M.A.F. (2014). The Relationship between Loyalty Program, Customer Satisfaction and Customer Loyalty in Retail Industry: A Case Study. Procedia - Social and Behavioral Sciences, 129, 23 - 30. https://doi.org/10.1016/j.sbspro.2014.03.643

Zeitamal \& Bitner. (2003). Service Marketing. Jakarta: Erlangga.

Publisher's Note: SSBFNET stays neutral with regard to jurisdictional claims in published maps and institutional affiliations.

\section{(a) (1)}

(C) 2021 by the authors. Licensee SSBFNET, Istanbul, Turkey. This article is an open access article distributed under the terms and conditions of the Creative Commons Attribution (CC BY) license (http://creativecommons.org/licenses/by/4.0/).

International Journal of Research in Business and Social Science (2147-4478) by SSBFNET is licensed under a Creative Commons Attribution 4.0 International License. 